ophthalmology. It was always a pleasure to work with him; he was so keen in everything that he undertook, and so long as his assistants were keen also he would spare no pains in his endeavour to help them. He loved teaching and so long as he was on the Staff no student at St. George's could fail to learn the most important elements of ophthalmic surgery. He did not write much; his book on the Fundus with illustrations by A. W. Head was his chief contribution to ophthalmic literature; the little text-book for students, which he wrote in collaboration with Brudenell Carter was never so well known as it deserved to be. His model artificial eye for teaching the use of the ophthalmoscope is very efficient for its purpose, more so than any other that I am acquainted with. Frost's keenness went beyond his work; he was an enthusiastic cyclist and, later, motorist; he hunted, he golfed, he played bridge, he enjoyed all that he did. It was a tragedy that in the last years of his life, he who had done so much to help the sight of others, should himself become blind, but he faced this calamity with patient courage.

The position of the specialists to St. George's Hospital, when Frost was appointed ophthalmic surgeon, was an anomalous one; they were elected by the Medical Committee as lecturers in their specialty, and then appointed by the Hospital Board to look after the cases referred to them by the surgical and medical staff. This appointment was for five years, at the end of which term they were eligible for re-election. It was during Frost's term of office and largely as a result of his personality that this anomaly was ended, and the specialists became a recognized part of the Hospital staff.

\title{
DR. CLARENCE LOEB
}

WE were sorry to see an obituary notice of Dr. Loeb in the October number of the Amer. Jl. of Ophthal. Our readers will, we think, be interested in a short abstract of this notice, for Dr. Clarence Loeb's name was very well known in this country.

Dr. Loeb was born in 1876 and received his training at the University of Missouri, where he graduated M.A. in 1897. Two years later he graduated in medicine from the Marion Sims College and after holding the usual appointments in the St. Louis City Hospital, he came to Europe for post-graduate ophthalmological study in Berlin and Vienna.

On his retturn to the States he was appointed Ophthalmic Surgeon to his old hospital and later became Assistant Professor of Ophthalmology in the St. Louis University.

Dr. Loeb's literary alibity was well known and was such that he was, for many years, Associate Editor of the Amer. Jl. of 
Ophthal., as well as Editor of the Trans. Amer. Acad. of Ophthal. and Oto-laryng.

He was the author of numerous papers and he translated Franke's "Ocular Therapeutics."

Dr. Loeb "was a man of sterling uprightness and unimpeachable character, strictly ethical ... and straightforward ...." No better tribute to a man's life-work could be made than this. His health broke up about five years ago and he died on May 26, 1935 .

His premature loss is a great blow to ophthalmology.

\section{GEORGE YOUNG, M.D., of Colchester}

Dr. George Young, Ophthalmic Surgeon to the Essex County Hospital, whose death at the early age of sixty occurred on October 30, was born in Bucharest, where his father, Dr. Young, was attached to the Court in a medical capacity.

He was educated at Zürich and studied medicine there and in Philadelphia, taking his M.D. Zürich in 1901. In 1902 he came to England and took his M.R.C.S., L.R.C.P. He worked in the Ophthalmic Department at the London Hospital under Roxburgh and also at Moorfields, where he became a clinical assistant. $\mathrm{He}$ also studied under Professor Fuchs in Vienna. In 1908 Young went to the United States, qualifying there by obtaining the M.D., New York State, and he practised in New York until 1914. He was Assistant Surgeon to the New York Eye and Ear Infirmary and Ophthalmic Surgeon to the Central and Neurological Eye and Ear Infirmary, and did much work in association with the late Dr. Marple. On returning to England in 1914 he immediately volunteered for the Army, but was not accepted, so he settled in Colchester, where he was appointed Ophthalmic Surgeon to the Essex County Hospital and he did much valuable work amongst the soldiers during the war.

As can be gathered from his professional record, he was an extremely good linguist, and a man of very wide experience. In his professional work the subject that probably interested him most was the treatment of glaucoma. He was very enthusiastic about the miotic treatment of suitable cases, and he worked out with the tonometer how frequently pilocarpine had to be used to keep the tension within normal limits and found that he was able to control cases satisfactorily by this method. For those requiring surgical treatment he devised the operation known as double sclerectomv and published his first results in the Trans. Ophthal. Soc. U.K., in 1924, and he described the operation again with his latest modifications at the last meeting of the 